\title{
a província de santa catarina na primeira metade do século xix: ensaio sobre opressão econômica e suas repercussões ${ }^{\star}$
}

\section{the province of santa catarina in the first half of the 19th century: an essay on economic oppression and its repercussions}

\author{
Hoyêdo Nunes Lins $\star \star ~$ \\ Universidade Federal de Santa Catarina, Florianópolis, SC, Brasil
}

RESUMO

A história moderna exibe ações de poder em que Estados se impõem a outros e partes de uma unidade política fazem o mesmo a outras, provocando-lhes adversidades. $\mathrm{O}$ artigo explora esse assunto, abordando as relações entre Portugal e Brasil do final do século XVIII a meados do século XIX, com realce para a situação da Província de Santa Catarina. Examinam-se os efeitos do Alvará português de 1785, que proibiu a produção têxtil no Brasil, e da abertura dos portos em 1808, quando um novo Alvará revogou o anterior e se firmou um tratado comercial com a Grã-Bretanha. Salientam-se os reflexos em Santa Catarina, falando de atividades industriais e pesca da baleia, e se contextualizam as ações sobre imigração, destacando a Colônia do Saí, inicialmente saudada com entusiasmo por conta das adversidades.

Palavras-chaves: Relações Portugal-Brasil. Proibição de manufaturas. Abertura comercial. Santa Catarina. Colonização.

\section{Abstract}

Power relations among states or among parts of empires mark modern history. Political units impose conditions on others, weaker ones, adversities normally arising in the latter. The article explores this issue by examining the Portugal-Brazil relations from the last decades of the 18th century to the middle of the 19th century, highlighting the situation of the Province of Santa Catarina.The effects of the Portuguese Alvará of 1785 prohibiting textile production in the colony are looked upon, and also the ports opening in 1808, followed by a new Alvará revoking the previous ban and by a trade treaty with Great Britain that largely benefited this nation. The conditions in Santa Catarina are described, focusing on its manufacturing and whaling. Positions concerning immigration, specially involving the Saí Colony, are considered.

Keywords: Portugal-Brazil relations. Ban of têxtiles production. Trade opening. Santa Catarina. Colonization.

\footnotetext{
* Submissão: 12/06/2020; aprovação: 15/11/2020.

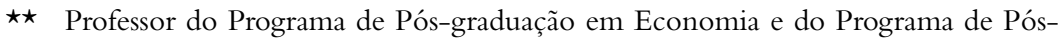
-graduação em Relações Internacionais da Universidade Federal de Santa Catarina. E-mail:hoyedo.lins@ufsc.br.ORCID:<https://orcid.org/0000-0001-7438-2951>
} 


\section{Introdução}

A trajetória do mundo moderno é crivada de relações entre unidades políticas, como Estados, ou entre partes de uma mesma unidade, como impérios, que representam opressão nas suas latitudes mais frágeis. Onde incidiu, esse exercício de poder geralmente produziu ou agravou adversidades por inibir ou impedir o florescimento das potencialidades existentes ou a continuidade de práticas tradicionais. Isso nem sempre derivou do uso da força, pois também interações comerciais ajudaram a atrofiar, devido à concorrência, a progressão de atividades nos elos mais frágeis da economia mundial.

Esse é o assunto geral deste estudo. Concretamente, o trabalho focaliza sobretudo a primeira metade do século XIX, que no Brasil "começou" com o deslocamento da corte portuguesa para a maior e mais rica colônia daquele império. O olhar mais atento se dirige à Província de Santa Catarina, cujos principais núcleos urbanos eram (por ordem de surgimento) Nossa Senhora do Rio São Francisco (1645) - atual São Francisco do Sul, no litoral norte -, Nossa Senhora do Desterro (1673) - atual Florianópolis, no centro do litoral - e Santo Antônio dos Anjos da Laguna (1676) - atual Laguna, no litoral sul; no interior do território figurava Nossa Senhora dos Prazeres dos Campos das Lajens (1766) - atual Lages. Desterro sempre foi a capital da província; sua denominação tornou-se Florianópolis somente em 1894.

O principal objetivo é explorar a questão dos efeitos no Brasil, destacadamente em Santa Catarina, de medidas governamentais sobre a indústria e o comércio, executadas pelo governo português durante a colônia e pelo governo brasileiro após a Independência. Baseada em fontes documentais históricas e inspirada também em literatura acadêmica, a abordagem está impregnada do que Ginzburg (1980) designa como paradigma conjectural da semiótica, cujo método envolve a tentativa de edificar conhecimento a partir de fragmentos dos assuntos estudados. Isso quer dizer atribuição de relevância aos sinais e pistas, já que, mesmo opaca, a realidade pode ser traduzida ou decodificada pelos indícios encontrados e analisados.

Saliente-se que em pesquisa histórica os sinais e pistas são aqueles disponibilizados notadamente por documentos, cujo estudo e cuja utilização se confundem, para Michel Foucault, com o próprio "fazer" da 
história. De fato, em relação ao documento, a história “[...] considera como sua tarefa primordial [...] trabalhá-lo no interior e elaborá-lo: ela o organiza, recorta, distribui, ordena e reparte em níveis, estabelece séries, distingue o que é pertinente do que não é, identifica elementos, define unidades, descreve relações." (Foulcault, 2007, p. 7).

O texto possui cinco partes, excluindo a introdução e as considerações finais. Primeiramente, caracteriza-se o período de estudo, de desafios para diversas sociedades externas ao centro do capitalismo por conta da opressão manu militari de países europeus, e aborda-se a proibição portuguesa de atividades industriais no Brasil. Depois, utilizando a ideia de “opressão pelo comércio", fala-se dos reflexos, antes e depois da Independência, da abertura comercial promovida com a transferência da corte para o Brasil em 1808. Na terceira parte, focaliza-se a Província de Santa Catarina, destacando as parcas possibilidades locais, um quadro que, segundo autoridades do período, foi agravado pela concorrência de produtos estrangeiros. $\mathrm{Na}$ quarta parte são tecidas algumas considerações sobre a pesca da baleia, que declinou dramaticamente por conta, em boa medida, da concorrência de barcos estrangeiros. Na quinta parte indica-se que as adversidades amargadas na província nutriram discursos pela imigração europeia nas primeiras décadas do século XIX, e alude-se a uma tentativa peculiar de colonização na área do Saí, no atual Município de São Francisco do Sul.

\section{Opressão de tipo manu militari e reflexos no Brasil}

Quase sempre rimaram com coerção e opressão as relações entre Estados que se projetaram além das suas fronteiras, em investidas de conquista ou dominação, e as sociedades atingidas. A manifestação da opressão, especificamente, costuma ser variada, como observa Markusen (1981) em estudo sobre o tema do regionalismo. Seus matizes são políticos, culturais e socioeconômicos, os últimos vinculados às dificuldades impostas às estruturas produtivas e à reprodução da força de trabalho nos ambientes afetados.

Não é dificil encontrar esse escopo da opressão nas relações internacionais. Na literatura sobre o imperialismo, cujo período áureo se desdobrou entre as últimas décadas do século XIX e o começo da Primeira Guerra 
Mundial, uma multifacetada opressão transpareceu nas interações entre potências europeias - que retalharam política e administrativamente, manu militari, a África e partes da Ásia - e territórios ultramarinos subjugados (Lénine, [1917] 1979).

Não que os problemas assim impostos tivessem começado nesse período. Por exemplo, "Para defender suas indústrias têxteis, [...] a Inglaterra, em 1700 e 1720, a França em 1686, proíbem a venda, em território nacional, dos tecidos da Índia." (Braudel, 1998b, p. 531). A rigor, a opressão, estribada em maior ou menor grau na capacidade de coagir (expressa em forças militares e policiais e em armas), marcou toda a longa trajetória dos Estados europeus, ajudando a explicar suas diferenças desde, pelo menos, o início do segundo milênio, como argumenta Tilly (1990). Contudo, sob o signo do imperialismo a opressão econômica manifestou-se de modo especialmente forte, mostrando-se a opressão social como caudatária e a política como tributária, a cultural expressando-se inclusive em racismo.

Da dinâmica do imperialismo resultou, com destaque na literatura, a destruição da indústria que existia historicamente em territórios que foram dominados. Na esteira da Revolução Industrial, os avanços técnicos e tecnológicos na produção (não só) têxtil permitiram à Grã-Bretanha conquistar o mercado indiano (Wallerstein, 1998). A consequência foi o sistemático aniquilamento das respectivas atividades locais, no que se conjugaram "[...] meios econômicos (proibições de importação na Inglaterra) e extra-econômicos (destruição das cidades industriais de Surat, Dacca, Murshidabad etc.), [...] [com imposição da] especialização agrícola [...].” (Amin, 1973, p. 262).

Daí ter Marx ([1867] 1976) ressaltado que a entrada em avalanche de tecidos de algodão britânicos provocou forte crise social em várias regiões da Índia. É que essa economia “[...] acabou sendo, no século XIX, 'desindustrializada', reduzida ao papel de um grande produtor de matérias-primas.” (Braudel, 1998b, p. 484). Através de meios políticos e militares, com suas condições determinadas pelo país imperialista, a opressão traduzida em brutal regressão econômica mostrou-se, com efeito, de corpo inteiro: "Um povo que em outro tempo exportava tecidos de algodão para todo o mundo, agora só exporta algodão que será transformado na Grã-Bretanha, para ser depois reexportado à Índia na forma de tecidos." (Mandel, 1969, p. 64). 
Tentativa de opressão com sentido semelhante caracterizou as relações entre Portugal e suas colônias, notadamente a maior delas, o Brasil. Um adequado ângulo de observação do assunto envolve considerar a situação daquele país em termos mais amplos. Cabe especialmente assinalar que, embora tivesse constituído um sistema com presença na Ásia, na África e no continente americano, Portugal passara a figurar na semiperiferia de uma enorme estrutura em cujo núcleo a Grã-Bretanha, particularmente em virtude dos desdobramentos da Revolução Industrial, sobressaía cada vez mais desde meados do século XVIII (Wallerstein, 1984).

No bojo de vínculos intensificados por tratados comerciais, como os de Methuen (em 1703 e 1713), durante o século XVIII a Grã-Bretanha introduziu no país ibérico "[...] seus tecidos, em fardos fechados, o suficiente para vestir todos os camponeses de Portugal [...]" (Braudel, 1998a, p. 181). Isso refletia o processo pelo qual, logo após aquele tratado, as compras portuguesas na Grã-Bretanha multiplicaram-se velozmente, em contraste com a tímida expansão das vendas do segundo país na direção contrária. $\mathrm{O}$ efeito mais catastrófico foi o virtual aniquilamento da indústria têxtil lusitana (Wallerstein, 1984).

Nesse contexto, ampliava-se ainda mais a importância para Portugal dos recursos existentes na sua mais rica colônia, parte da qual fora incorporada desde o século XVI como periferia no sistema mundial mediante tipo de processo teorizado por Hopkins e Wallerstein (1987). $\mathrm{O}$ açúcar e o ouro brasileiros, em particular, eram essenciais para a condição portuguesa no período. Assim, revelaram-se muito graves, para Portugal, os problemas que se instalaram e se aprofundaram na colônia tanto no front açucareiro como no da mineração. De acordo com Frank (1977), o açúcar brasileiro mostrava-se cada vez menos capaz de fazer frente à concorrência do produto originário das Antilhas, sob comando francês. E as minas de ouro brasileiras, amargando forte queda da produção desde meados do século XVIII, perdiam mais e mais a capacidade de responder às necessidades portuguesas quanto à quitação das compras de produtos britânicos.

Entre as respostas de Portugal figuraram ações fiscais e para garantir exclusividade na exploração econômica do Norte da colônia.Ao mesmo tempo, o Estado ibérico estimulou a produção manufatureira, principalmente têxtil, no território metropolitano. Entretanto, era a ampliação do controle sobre a economia colonial que figurava como principal 
instrumento na busca portuguesa por uma maior independência econômica (Wallerstein, 1998).

As circunstâncias impunham, de fato, tal estratégia, já que, mesmo com a expansão da sua manufatura têxtil, parte considerável das vendas externas de Portugal consistia de reexportações de manufaturados vindos da Grande-Bretanha. Realmente, no século XVIII, cerca de 1/5 dessas exportações britânicas dirigiam-se a Portugal, com os tecidos dessa origem mostrando-se suficientes para fazer "[...] submergir o mercado longínquo do Brasil" (Braudel, 1998a, p. 181). Na contramão, o ouro extraído no Brasil rumava para a Grã-Bretanha, da qual Portugal não representava muito mais, na prática, do que uma colônia comercial.

Por conta disso, aliás, as relações de comércio entre a maior potência europeia e Portugal teriam se traduzido em influência britânica no Brasil com intensidade muito maior do que o observado na maior parte da América espanhola (Wallerstein, 1984). De todo modo, a presença britânica e suas consequências no Novo Mundo foram amplas. A administração colonial espanhola revelou-se sintonizada, a partir das últimas décadas do século XVIII, com os interesses comerciais da Grã-Bretanha, e isso contribuiu para arruinar a produção manufatureira nesses territórios (Quijano; Wallerstein, 1992). Essa manufatura, observe-se, decorrera da busca de opções em face das turbulências vivenciadas na América espanhola no século XVII, um processo no qual a fabricação de tecidos, sabão, artigos de couro e lamparinas de sebo, entre outros, instalou-se em locais como Quito, Nova Granada e Cuzco (Braudel, 1998a).

Foi nesse cenário que, em 5 de janeiro de 1785, o Estado português, tendo à frente a rainha D. Maria I, emitiu Alvará interditando a produção de manufaturados nas suas colônias. Seu texto é o seguinte:

EU A RAINHA Faço saber aos que este Alvará virem: Que sendo-me presente o grande número de Fabricas, e Manufacturas, que de alguns anos a esta parte se tem diffundido em diferentes Capitanías do Brazil, com grave prejuízo da Cultura, e da Lavoura, e da exploração das Terras Mineraes daquele vasto Continente; porque havendo nelle huma grande, e conhecida falta de População, he evidente, que quanto mais se multiplicar o número dos Fabricantes, mais diminuirá o dos Cultivadores; e menos Braços haverá, que se possão empregar no descubrimento, e rompimento de huma grande parte daqueles extensos Dominios, que ainda se acha inculta, e desconhecida: Nem as Sesmarias, que formão outra considerável parte dos mesmos Do- 
minios, poderão prosperar, nem florecer por falta do beneficio da Cultura, não obstante ser esta a essencialíssima Condição, com que forão dadas aos Proprietarios delas: E até nas mesmas Terras Mineraes ficará cessando de todo, como já tem consideravelmente diminuído a extracção do Ouro, e Diamantes, tudo procedido da falta de Braços, que devendo empregar-se nestes uteis, e vantajosos trabalhos, ao contrario os deixão, e abandonão, ocupando se em outros totalmente diferentes, como são os das referidas Fabricas, e Manufacturas: E consistindo a verdadeira, e sólida riqueza nos Frutos, e Producções da Terra, as quaes somente se conseguem por meio de Colonos, e Cultivadores, e não de Artistas, e Fabricantes: e sendo além disto as Producções do Brazil as que fazem todo o fundo, e base, não só das Permutações Mercantis, mas da Navegação, e do Commercio entre os Meus Leaes Vassallos Habitantes destes Reinos, e daqueles Dominios, que devo animar, e sustentar em comum beneficio de huns, e outros, removendo na sua origem os obstáculos, que lhe são prejudiciais, e nocivos: Em consideração de tudo o referido: Hei por bem Ordenar, que todas as Fabricas, Manufacturas, ou Teares de Galões, de Tecidos, ou de Bordados de Ouro, e Prata; De Velludos, Brilhantes, Setins, Tafetás, ou de outra qualquer qualidade de Seda: De Belbutes, Chitas, Bombazinas, Fustões, ou de outra qualquer qualidade de Fazendas de Algodão, ou de Linho, branca, ou de cores: E de Pannos, Baetas, Droguetes, Saetas, ou de outra qualquer qualidade de Tecidos de Lã, ou os ditos Tecidos sejão fabricados de hum só dos referidos Generos, ou misturados, e tecidos huns com os outros; exceptuando tão somente aquelles dos ditos Teares, e Manufacturas, em que se tecem, ou manufacturão Fazendas grossas de Algodão, que servem para o uso, e vestuário dos Negros, para enfardar, e empacotar Fazendas, e para outros Ministerios semelhantes; todas as mais sejão extinctas, e abolidas em qualquer parte onde se acharem nos Meus Dominios do Brazil, debaixo da Pena do perdimento, em tresdobro, do valor de cada huma das ditas Manufacturas, ou Teares, e das Fazendas, que nelas, ou nelles houver, e que se acharem existentes, dousmezes depois da publicação deste; repartindo-se a dita Condemnação metade a favor do Denunciante, se o houver, e a outra metade pelos Officiaes, que fizerem a Diligencia; e não havendo Denunciante, tudo pertencerá aos mesmos Officiaes. [...]

Dado no Palacio de Nossa Senhora da Ajuda, em 5 de Janeiro de 1785. = Com a Assignatura da Rainha, e a do Ministro.

(Alvará..., 1828, p. 370-371) 
Diversos autores examinaram esse documento, e todos ressaltaram, com mais ou menos contundência, o significado para a colônia sul-americana da rápida extinção das "Fabricas, Manufacturas, ou Teares, e das fazendas", poupando-se apenas a produção de "Fazendas grossas de Algodão".

Varnhagen (1857, p. 268) qualificou a proibição como “[...] talvez o acto mais arbitrário e opressivo da metrópole contra o Brazil, desde o princípio do reinado anterior [...]". Britto (1939, p. 214-215) assinalou que "Ninguém negará a repercussão desastrosa dessa extorsão [...]. A metrópole feria de morte a indústria fabril do Brasil [..., ] arrebatando-lhe os minguados aparelhos de que se servia para o fabrico de tecidos e de chapéus.". Caio Prado Jr., frisando que na segunda metade do século XVIII tinham surgido manufaturas têxteis em Minas Gerais e no Rio de Janeiro, escreveu que o Alvará "Era o golpe de morte na indústria da colônia; e isto apesar da exceção que a lei incluíra [...].” (Prado Júnior, [1942] 1961, p. 223).

De toda maneira, não há consenso na literatura sobre as consequências práticas da interdição para a produção têxtil da colônia. Furtado ([1959] 1987) diz ter sido fraca a reação ao Alvará, o que espelhava um diminuto crescimento manufatureiro anterior, expressão da escassa capacidade técnica local para desenvolver esse tipo de atividade em volume expressivo. Mesmo na capital da colônia a presença era limitada. Britto (1939), aludindo a levantamento feito no Rio de Janeiro pouco antes da proibição das fábricas, fala em somente cinco pessoas detentoras de treze teares para tecidos de ouro e prata e de onze pessoas com teares para tecidos de lã, linho e algodão. Lessa (2000, p. 125) diz que nessa cidade a segunda metade do século XVIII assistiu a não mais que "[...] uma poeira de ensaios manufatureiros".

Assim, tem sentido dirigir o olhar para além das motivações aparentes da proibição, indicadas no início do Alvará.A razão apontada, em síntese, era que a recente multiplicação das fábricas e manufaturas prejudicava a agricultura e a mineração na colônia, por reduzir a disponibilidade de trabalhadores para essas atividades. Tal escassez afetaria as estratégicas e necessárias descoberta e exploração de novas áreas e de novos recursos no território. A inquietação em face disso, que transparece no Alvará, tinha como principal motivo o fato de que eram, como reconhecido em trecho que aqui se repete, "[...] as Producções do Brazil as que fazem 
todo o fundo, e base, não só das Permutações Mercantis, mas da Navegação, e do Commercio entre os Meus Leaes Vassallos Habitantes destes Reinos, e daqueles Dominios [...]”. (Alvará..., 1828, p. 370).

Ponderações sobre os motivos da interdição crivam a, por assim dizer, exegese do Alvará de 1785 efetuada por Novais (2000). Segundo esse autor, para compreender o sentido do documento é preciso colocá-lo em perspectiva, em relação à política colonial protagonizada por Portugal nas últimas décadas do século XVIII, a qual, por seu turno, fazia parte da política econômica mais geral desse país naquele período. Mais especificamente, é preciso considerar a situação de Portugal no sistema europeu de então, mormente em face da Grã-Bretanha.

A precária situação econômica de Portugal agravava o significado da progressiva queda da arrecadação dos quintos ligados à produção de ouro, um problema claramente indicado no Alvará. Também preocupavam os resultados do comércio entre Portugal e Brasil. Simonsen (2005) relata que na segunda metade do século XVIII essa colônia canalizava mais de $80 \%$ das exportações da metrópole, e que metade das vendas de Portugal para o mundo provinha do Brasil (tabaco, algodão, cacau, baunilha, cravo, anil, entre outros produtos), mostrando-se a balança do comércio metrópole-colônia frequentemente favorável à segunda, como documentado por aquele autor para o período 1796-1819. E o contrabando para o Brasil, amplamente realizado por britânicos, juntava-se aos processos que afetavam as vendas portuguesas para a colônia, do que davam prova os registros alfandegários.

Assim, reconhecia-se na corte que "[...] o desenvolvimento manufatureiro de Portugal não podia prescindir do mercado colonial; a colônia porém já começa a dar mostras das primeiras e frágeis tendências para desenvolvimento autônomo." (Novais, 2000, p. 218). Portanto, foi o declinante desempenho comercial de Portugal nas relações com o Brasil, repercutindo nas atividades fabris da metrópole, que subjazeu, antes de tudo, à emissão do Alvará.

Manufaturas coloniais, descaminhos, contrabandos convergem em idênticos efeitos sobre a economia portuguesa, que [...] não podia dispensar os estímulos do mercado colonial para consolidar seu esforço industrialista. Ao determinar a supressão das manufaturas existentes no Brasil [...], bem como ao intentar coibir a penetração de economias mais desenvolvidas no 
mercado ultramarino, a política colonial portuguesa reage a uma situação de fato, que deve ser encarada com objetividade [...]. (Novais, 2000, p. 223-224)

\section{Da opressão manu militari àquela relacionada ao comércio}

A opressão manu militari representada pelo Alvará de 5 de janeiro de 1785 saiu de cena com a chegada da família real portuguesa ao Brasil, em 1808. Deixando Lisboa sob a proteção da marinha britânica em face da investida de Napoleão, a corte se instalou no Rio de Janeiro após breve passagem por Salvador.

Iniciativa muito importante do príncipe-regente de Portugal, D. João de Bragança, ao desembarcar em Salvador em 24 de janeiro de 1808, foi abrir os portos do Brasil às nações amigas. Isso ocorreu mediante Carta Régia promulgada meros quatro dias depois, devendo-se assinalar que a Grã-Bretanha era a mais amiga entre todas as referidas nações. Nessa declaração se estipulou taxa alfandegária de $24 \%$ sobre os produtos importados, com exceção de "vinhos, aguas ardentes e azeites doces, que se denominam molhados, pagando o dobro dos direitos [...]" (Carta Régia, 1808, p. 1).

Interessa sobretudo registrar que, pouco depois da sua chegada ao Rio de Janeiro (em 8 de março), o monarca revogou o documento proibitório da produção fabril, vigente havia 23 anos. A revogação ocorreu com o Alvará de $1^{\circ}$ de abril de 1808 , cujo texto é apresentado a seguir.

Eu O Principe Regente, faço saber aos que o presente Alvará virem: Que desejando promover e adiantar a riqueza nacional, e sendo hum dos mananciaes della as manufacturas e a indústria que multiplicão e melhorão e dão mais valor aos generos e productos da agricultura e das artes e augmentão a população dando que fazer a muitos braços e fornecendo meios de subsistencia a muitos do meus vassallos que por falta delles se entregarião aos vicios da ociosidade: e convindo remover todos os obstaculos que podem inutilizar e frustrar tão vantajosos proveitos: sou servido abolir e revogar toda e qualquer prohibição que haja a este respeito no Estado do Brasil e nos meus Dominios Ultramarinos e ordenar que daqui em diante seja licito a qualquer dos meus vassallos, qualquer que seja o paiz em que habitem, 
estabelecer todo o genero de manufacturas, sem exceptuar alguma fazendo os seus trabalhos em pequeno, ou em grande, como entenderem que mais lhes convém; para o que hei por bem derogar o Alvará de 5 de Janeiro de 1785, e quaisquer Leis ou Ordens que o contrario decidão, como se delas fizesse expressa e individual menção, sem embargo da Lei em contrario.

Pelo que mando, etc. Dado no Palacio do Rio de Janeiro em o $1^{\circ}$ de Abril de 1808. - PRINCIPE com Guarde.- D. Fernando José de Portugal.

(Alvará..., 1836, p. 4)

A proteção tarifária anteriormente definida, nos termos da Carta Régia de janeiro, foi logo depois alterada para nível muito inferior, em decreto de 11 de junho de 1808. Nesse documento se ordenava, argumentando ser necessário remover os entraves ao comércio e revitalizar uma combalida economia,

[...] que todas as fazendas e mercadorias que forem proprias dos meus vassallos, e por sua conta carregadas em embarcações nacionaes, ao entrarem nas Alfandegas do Brazil, paguem de direito por entrada dezeseis por cento sómente; e os generos que se denominam molhados paguem menos a terça parte do que se acha estabelecido [...]. (Brasil, 1808)

Esse rebaixamento representou grande beneficio para a Grã-Bretanha, devido ao poderio da sua indústria. A vantagem obtida cresceu ainda mais quase dois anos depois, por conta do Tratado de Comércio e Navegação firmado entre os dois países em 19 de fevereiro de 1810. Passagens relevantes, considerando-se o ângulo aqui ressaltado, encontram-se a seguir (Tratado..., 1836, p. 242-249).

TRATADO de commercio e navegação, entre os muito altos, e muito poderosos senhores o Principe Regente de Portugal, e El-Rei do Reino-Unido da Gram-Bretanha e Irlanda, assignado no Rio de Janeiro pelos Plenipotenciarios de huma e outra Côrte, em 19 de Fevereiro de 1810, e ratificado por ambas. [...]

Art. 2. ${ }^{\circ}$ Haverá reciproca liberdade de commercio e navegação entre os respectivos vassallos das duas altas partes contractantes em todos, e em cada hum dos territorios e domínios de qualquer delas. Elles poderão negociar, 
viajar, residir ou estabelecer-se em todos, e cada hum dos portos, cidades, villas, paizes, províncias ou lugares, quaisquer que forem, pertencentes a huma ou outra das duas altas partes contractantes; excepto naquelles de que geral e positivamente são excluídos todos quaesquer estrangeiros [...]

Art.3. ${ }^{\circ}$ Os vassallos dos dous soberanos não pagarão respectivamente nos portos, bahias, enseadas, cidades, villas ou lugares quaesquer que forem, pertencentes a qualquer deles, direitos, tributos ou impostos [...] maiores do que aquelles que pagão ou vierem a pagar os vassallos da nação a mais favorecida: e os vassallos de cada huma das altas partes contractantes gozarão nos domínios da outra dos mesmos direitos, privilegios, liberdades, favores, imunidades ou isenções em materias de commercio e de navegação, que são concedidos ou para o futuro o forem aos vassallos da nação a mais favorecida. [...]

Art. 15. ${ }^{\circ}$ Todos os generos, mercadorias e artigos quaesquer que sejão, da producção, manufactura, industria ou invenção, dos domínios e vassallos de Sua Magestade Britannica, serão admittidos em todos, e em cada hum dos portos e dominios de Sua Alteza Real o Principe Regente de Portugal, tanto na Europa como na America, Africa e Asia, quer sejão consignados a vassallos Britannicos, quer a Portuguezes, pagando geral e unicamente direitos de quinze por cento $[\ldots]$.

Os direitos alfandegários caíram para não mais que 15\%, em comércio bilateral envolvendo o país mais rico e industrializado do mundo. Furtado ([1959] 1987, p. 93-94) não contemporizou ao apontar o enorme privilégio concedido à Grã-Bretanha: tratados como esse, "[...] com direitos de extraterritorialidade e tarifas preferenciais a níveis extremamente baixos, [...] constituirão, em toda a primeira metade do século [XIX], uma séria limitação à autonomia do governo brasileiro no setor econômico."

Assim, mesmo que a proibição das práticas industriais na colônia tivesse desaparecido, a indústria permaneceu defrontada com importantes adversidades no Brasil. Como salientou Prado Júnior ([1942] 1961, p. 223), a produção têxtil tinha

[...] de lutar com fatores adversos muito sérios, de que não foi o menor a concorrência tão bem aparelhada, industrial e comercialmente dos tecidos ingleses, favorecidos pelo franqueamento do comércio externo da 
colônia, e pouco depois, pelas vantagens apreciáveis que lhes concedeu o tratado de 1810.

A maior potência europeia não perdeu regalia com a Independência do Brasil: em 1822, D. Pedro I torna-se imperador "[...] com a benção e sob a proteção da Grã-Bretanha." (Wallerstein, 1998, p. 356). Assim, as ações para promover a indústria na agora ex-colônia iriam

[...] tornar-se sem efeito diante das imposições do mais forte. [...] Entregava-se às manufaturas inglesas o mercado brasileiro, inutilizando todos os esforços despendidos [...] a favor das fábricas nacionais. Nos anos seguintes presenciaremos uma espécie de nacionalismo económico às avessas - para libertar-se dessa situação vexatória em relação à Grã-Bretanha, o governo brasileiro foi concedendo [...] às outras nações os privilégios auferidos pelos ingleses. Pelo decreto de 28 de setembro de 1828 todas as mercadorias estrangeiras passaram a pagar direitos aduaneiros na razão de $15 \%$, qualquer que fosse a sua nacionalidade. A supremacia incontestável da Grã-Bretanha no mercado brasileiro não foi porém, no momento, comprometida. (Luz, 1978, p. 22-23)

Nos anos 1840, procurou-se instituir uma nova política de proteção às atividades industriais no Brasil, em linha com as aspirações de algumas lideranças em torno da dinamização da economia. Luz (1978) observa que uma nova pauta alfandegária foi outorgada pela Assembleia Geral em 1841, com direitos que variavam de $2 \%$ a 60\%, e que em 1844 a Tarifa Alves Branco passou a incidir em cerca de três mil produtos: 60\% para importações de similares aos brasileiros e 30\% para não similares. Embora o favorecimento à indústria têxtil não tenha sido expressivo naquele momento, ainda assim

As fábricas de tecidos de algodão foram [...] agraciadas, em 1846, com uma série de privilégios, para compensar, talvez, a proteção inadequada que a nova pauta lhes dispensava. Foi também confirmada, em 1847, a concessão de isenções de direitos aduaneiros às matérias-primas destinadas às fábricas nacionais. (Luz, 1978, p. 25)

Mesmo no Rio de Janeiro os reflexos industriais foram limitados. Lessa (2000, p. 170) afirma que, de uma maneira geral, a cidade "[...] foi 
urbanizada sem que houvesse a industrialização". Surgiram nessa cidade, nas últimas décadas do século XIX, algumas fundições de ferro, fábricas de tecidos, pequenas manufaturas de chapéus, fivelas, sabão e cera, gráficas e unidades de processamento de alimentos, de rapé e de produção de bebidas. Também passaram a ser ofertados materiais para construção civil, e uma indústria têxtil de maior porte apareceu no final do século, assim como a produção de fogões, depois que se começou a fabricar embarcações a vapor. Entretanto, adverte Lessa (2000, p. 172), “É um erro confundir a presença desta 'poeira' de manufaturas com a consistência de um processo de industrialização."

\section{A Província de Santa Catarina em face das restrições produtivas}

A opressão, com os aspectos anteriormente considerados, não deixou de repercutir na Província de Santa Catarina, particularmente na sua capital. Merece registro, no tocante à situação decorrente do Alvará de 1875, o caso do Padre Lourenço, nascido em 1767 na freguesia de Nossa Senhora das Necessidades de Santo Antônio, atual Santo Antônio de Lisboa, na Ilha de Santa Catarina.

Ordenado em seminário no Rio de Janeiro no ano da emissão do Alvará, Padre Lourenço retornou ao Desterro e, nas suas atividades, costumava se manifestar fortemente contra a proibição das manufaturas têxteis e a consequente extinção dos teares domésticos. O modo como demonstrava a sua crítica, envergando somente vestimentas produzidas nesses teares, teria sido por ele conservado quando do exercício da função de Deputado na corte portuguesa, em Lisboa, de 1821 a 1822, representando a Província de Santa Catarina (Memória..., 2018).

No período da proibição, especificamente em 1786, havia centenas de teares na Ilha de Santa Catarina e em freguesias mais ou menos próximas, conforme relatório enviado pelo governador da província ao vice-rei, no Rio de Janeiro. Segundo esse documento, estudado por Silva (2008), os teares se distribuíam como segue:Vila capital de N. Sra. do Desterro - 105; N. Sra. das Necessidades de Santo Antônio - 150; N. Sra. da Conceição da Lagoa - 88; São Miguel - 109; N. Sra. do Rosário da Enseada de Brito - 29. 
No tocante à qualidade e aos preços (em réis por vara, uma medida de comprimento então utilizada), o leque detectado era considerável. Faziam parte colchas, tanto de algodão e estopa quanto feitas com fios de bata, entre $4 \$ 000$ e $6 \$ 400$; toalhas, entre $\$ 640$ e $\$ 800$; panos, dos mais ordinários aos mais finos, entre $\$ 320$ e $\$ 400$; estopinhas e estopas, entre $\$ 200$ e $\$ 240$; riscados e fustões, de $\$ 400$ a $\$ 640$ (Silva, 2008).

Sobre o contexto da abertura dos portos às nações amigas, com o Alvará de $1^{\circ}$ de abril de 1808 e o tratado comercial e de navegação de 19 de fevereiro de 1810, cabe expor, sobre os reflexos na província, os discursos dos presidentes na Assembleia Legislativa. Em $1^{\circ}$ de março de 1838, o Brigadeiro João Carlos Pardal assim se pronunciou sobre a questão fabril:

Quanto à indústria fabril, ella consiste no fabrico de louça pela maior parte só propria para usos culinarios, no de flores de escamas, conchas, e pennas, em que se notão progressos na perfeição, e na construcção de poucos navios de mais de cem toneladas, e de outros de menor porte.

Hum ramo desta industria, que já foi mui florecente, acha-se hoje quasi em total decadencia, trato dos tecidos de algodão e de linho, que além de supprirem outr'ora todas as precisoens domesticas, fornecião grande copia à exportação. Provém o seu quase desaparecimento de que, tendo crescido o custo da producção, como o de todas as outras, não pode este genero concorrer com os tecidos estrangeiros, que posto inferiores sejão em duração, vem ao mercado por preços incomparavelmente inferiores. (Discurso..., 1838, p. 16l)

Dois anos depois, em ato da mesma índole, o então presidente, Marechal de Campo Francisco Joze de Souza Soares d'Andrea, mostrou-se incisivo na Assemblea Legislativa, em $1^{\circ}$ de março de 1840.

A indústria fabril entre nós, não passa de huma fraze vazia de sentido: esses mesmos mesquinhos e grosseiros tecidos a que se davão as classes mais indigentes, não tem podido sustentar-se, e vão a se aniquilar de todo; porque a concorrencia das fazendas estrangeiras a muito mais baixos preços, lhes dará o ultimo garrote. Em quanto os Ecconomistas Politicos se esfalfão em nos provar que a liberdade do commercio, sem restricção alguma, he a estrada mais franca para a ventura das Naçoens, e para o seu grande desenvolvimento, os Governos a que eles pertencem, repulsão toda a industria 
estrangeira, e seus fabricantes esquadrinhão quaes são as coizas que ainda se fazem nos países que tem aceitado as suas sabias doutrinas, e tratão de imitar essas fazendas, e esses últimos objectos, para os mandarem vender por preços tão diminutos, que dão logo cabo desses últimos ramos de industria; e assim nos vemos abstruídos de algodoens grossos, e até de lombilhos e caronas para que nem isto possamos fabricar. Ociozo he mostrar-vos estes males, que não estaes habilitados a remediar; porém estará talvez da vossa parte estabelecer algum premio [...] a hum certo numero de pessoas que apresentem em alguma feira ou mercado publico, o maior numero de produtos de seus próprios teares, em quanto por outro lado podeis dar preferencia nos uzos domésticos de vossas cazas aos tecidos da Provincia, e tornados assim em moda seguida, poderia ser considerável o seu consumo. Haveria outro meio, e talvez mais seguro para alentar a indústria fabril, e he estar por conta do Governo aberta sempre a compra por preços estipulados, [...] e desse Armazem venderem-se depois a quem mais desse, [...] para se deffundir por todos, na venda a retalho. (Discurso..., 1840, p. 27)

O caráter desses discursos não deveria surpreender, pois o quadro na província era de grandes dificuldades no início do século XIX. Seu litoral sempre se mostrou estratégico para a navegação - por exemplo, a área da Ilha de Santa Catarina, "[...] com razão foi ella, em virtude dos seus portos, e do seu clima e fertilidade, tida, como ainda hoje o deve ser, [...] paragem estratégica mais importante do Brazil, do Rio de Janeiro para baixo." (Varnhagen, 1857, p. 152-153). O comandante francês Louis I. Duperrey já havia constatado, em 1822, ser a baía norte do Desterro, "[...] depois do Rio de Janeiro, a melhor baía e mais considerável da América meridional [...]" (Ilha..., 1979, p. 272). Mas as condições de reprodução social mostravam-se preocupantemente limitadas na província.

A situação assim se apresentava, por exemplo, no final do século XVIII, cujo último decênio foi de grande miséria junto à população, repetida nos anos 1830 e, com maior duração, nos 1850 (Cabral, 1972b). Nesse período, fases expansivas da economia provincial diziam respeito, entre outros aspectos e com grande destaque, à produção de farinha de mandioca, que tinha no porto do Desterro o seu principal canal de exportação. Hübener (1981) informou que, no biênio 1849-1850, quase $60 \%$ dessa farinha exportada pela província foi embarcada nesse porto, dirigida principalmente para Rio Grande do Sul, Rio de Janeiro e províncias platenses. 
Mas era maior a pauta de embarques do porto do Desterro, que Cabral (1972b) diz ter sido muito frequentado e acompanhado, em escala de província, por atividades portuárias em Laguna, São Francisco e Porto Belo. Saint-Hilaire ([1851] 1936), que visitou Santa Catarina em 1820, registrou o embarque de óleo de baleia, cal, feijão, milho, amendoim, melado, madeira de construção e marcenaria, couro, louças de barro, peixe salgado, tecidos de linho e tecidos de cânhamo e algodão.Também algum açúcar e grandes quantidades de alho e cebola, além de café e pólvora, compunham os volumes.

Seja como for, comentando a escassa vitalidade econômica local durante a maior parte do século XVIII, Saint-Hilaire ([1851] 1936, p. 34) assinalou: "As prohibições impostas pelo governo tornavam o commercio quase nullo [...]". Embora reconhecendo existir potencial econômico na área, o autor ressaltou que

[...] a província é pobre. Os colonos que ali se estabeleceram [...] não prosperavam; a tyrannia do governo portuguez fora durante muito tempo um empecilho ao surto de qualquer iniciativa individual.Taes são as causas mais remotas da pobreza dessa província [...]. (Saint-Hilaire, [1851] 1936, p. 59-60)

Após a revogação do Alvará de 1785 que proibia a fabricação têxtil, e sob as novas condições de comércio, as relações comerciais com a Inglaterra não deixaram de repercutir na província. Por exemplo, as mulheres das camadas sociais populares, principalmente nos redutos rurais, conseguiam alguma renda com o trabalho de fiação e tecelagem: "[...] a qualquer hora do dia que se passe pelas suas casas ouve-se baterem o algodão" (Saint-Hilaire, [1851] 1936, p. 164). E as mulheres de famílias em melhor situação, sobretudo das mais abastadas, recorriam ao comércio do Rio de Janeiro, cujos padrões de vestimenta e ornamentação eram europeus, o que significava produtos importados.

A rigor, a grande presença de vários tipos de produtos estrangeiros era um proeminente traço da realidade catarinense, mormente no Desterro. Dão conta desse aspecto da vida local várias descrições contidas em Cabral (1972b) e mencionadas em diversos registros de visitantes, como observado em Ilha (1979).

As anotações desses visitantes - viajantes estrangeiros que eram, em 
geral, comandantes de navios de passagem pela Ilha (e pelo litoral mais ou menos próximo) entre os séculos XVIII e XIX - permitem também observar a prevalência de uma situação social geralmente problemática. Em alguns desses relatos mencionam-se as restrições impostas tanto manu militari como pelo comércio, no sentido discutido anteriormente, às atividades manufatureiras locais.

O capitão estoniano Adam J. von Krusenstern esteve na Ilha em 1803, como chefe de uma expedição russa, em plena vigência do alvará português que interditara a fabricação têxtil. Sobre o mencionado problema dos efeitos locais, esse viajante observou que “[...] os habitantes são proibidos de exportar seus produtos para qualquer outro lugar que não seja o Rio de Janeiro, [e] seu comércio permanece [...] na mais miserável das condições.” (Ilha..., 1979, p. 151).

O já referido Duperrey, que passou pela Ilha no período de abertura comercial e de forte entrada de produtos estrangeiros, descreveu com detalhes vários aspectos do cotidiano. Sobre a economia, destacou que

[...] os produtos da Ilha jamais excederam em muito no consumo dos habitantes, em geral pobres [...]. Os panos de linho e de algodão são os únicos tecidos manufaturados em Santa Catarina, apenas suficientes às necessidades dos habitantes. Quase todos os outros artigos são importados pelas embarcações nacionais ou estrangeiras. (Ilha..., 1979, p. 279)

Outro depoimento digno de menção, por mostrar-se bastante sugestivo, é o de René P. Lesson, naturalista da expedição de Duperrey. O viajante notou que algumas mulheres "[...] tecem fazendas de algodão; mas em geral sua indústria é bastante restrita, e é do Rio de Janeiro que se traz o pequeno número de artigos que compõem seus vestuários [...]" (Ilha..., 1979, p. 286).

Sendo disseminada a pobreza, o dia a dia era marcado pelo impulso à evasão. Cabral (1972b, p. 11) escreveu que em 1829 “[...] a Câmara do Destêrro foi advertida pelo Presidente da Província de que era grande o êxodo da população jovem, que aqui não encontrava meios de vida [...]. Havia para mais de 600 famílias no litoral da Província [...] na mais completa miséria [...]". Trabalhar como embarcado (em pesca ou comércio) era uma orientação que magnetizava bom número de interessados em tentar a vida alhures. 
Tal situação marcava diferentes famílias, constituindo ilustração o que se encontra registrado nas memórias de Luiz Nunes Pires, redigidas como depoimento para seu filho mais velho. Nascido na Ilha em novembro de 1790, o autor embarcou com 17 anos de idade e só retornou ao Desterro, para ficar, 14 anos depois. Explicando as razões da saída e da longa ausência, o autor assinalou, entre outros aspectos:"[...] bem conhecia que as terras de meo pai erão poucas para tantos filhos e que a minha partida deixaria mais lugar [...]" (Memórias..., [1829?] 1967, p. 5)

A estrutura produtiva da província não oferecia mais, de fato, do que escassas possibilidades. Escrevendo sobre a capital, Cabral (1972b) frisou que de algum vulto existia somente a atividade de extração e preparo do óleo de baleia. E, além da já aludida produção têxtil, afetada primeiro pela proibição portuguesa e depois pela concorrência inglesa, havia não muito mais do que olarias (tijolos e telhas) e fabricação de fogos, sabão e velas.

Brito (1829, p. 62), em estudo realizado em 1816, afirmou ter visto "[...] mui boas murcellinas, acolchoados, colchas para camas, e roupa de meza [...]". Registrou igualmente, e com admiração, a produção de artefatos (cordas, redes de pesca, sacaria e velames para embarcações) com a fibra extraída do gravatá, um arbusto naturalmente copioso na área. Também o peixe seco foi mencionado, com destaque sobretudo para a sua presença em Laguna.

Assim, se eram escassas as oportunidades de trabalho assalariado no Rio de Janeiro durante o século XIX, como nota Lessa (2000), muito mais exíguas eram as chances em província com as características de Santa Catarina. Entre os problemas que agravavam a situação local perfilava-se a precariedade nos transportes e comunicações, registrada por Saint-Hilaire ([1851] 1936) em 1820. Mesmo mais tarde, na década de 1880, Taunay (1926) constatou periodicidade apenas quinzenal na ligação entre o Desterro e São Francisco (litoral norte da província), com escala em porto intermediário correspondente a Itajaí.

Limitações desse tipo perduraram mesmo em quadro nacional de finanças públicas em que, entre a geração de receitas fiscais para o governo imperial e o recebimento de recursos distribuídos desde tal nível, a província catarinense ganhava bem mais do que proporcionava (Diniz, 2005). Assim, também pelas doações financeiras resultantes foi considerada fértil a visita feita ao Desterro por D. Pedro II e a Imperatriz The- 
resa Christina, desembarcados em 12 de outubro de 1845 e hospedados por vários dias. Tratou-se do mais importante acontecimento político desse período na província, embora fosse sucedido por outra visita desse monarca duas décadas depois e precedido por rápida passagem de D. Pedro I em 1826, rumo ao Rio Grande do Sul (Cabral, 1972a).

\section{Declínio da pesca da baleia, um sintoma da opressão}

O quadro de penúria então constatado na Província de Santa Catarina não surgiu de um momento para outro. Saint-Hilaire ([1851] 1936, p. 171) ofereceu a seguinte apreciação a respeito, com base no que registrou em 1820.

O início da decadencia de Santa Catharina data já de alguns annos atraz. Antes, existiam em toda a provincia 288 engenhos de assucar; em 1797 havia apenas 256; em 1820, exportava-se muito pouco assucar e hoje esse genero não mais figura entre os que a província ainda remette para fóra. Muito embora o abandono das armações não tenha exercido grande influência na economia da provincia, porque a diminuição da pesca já vinha de longo tempo e se foi operando progressivamente, é fora de duvida [...] que na época em que as mencionadas armações eram florescentes, havia maior riqueza, os habitantes das vizinhanças ganhavam bons salarios e o transporte de azeite de baleia fomentava a cabotagem.

Esse depoimento induz a considerações sobre uma prática histórica no litoral catarinense: a pesca da baleia. Atividade antiga em vários continentes e observada ao longo da costa brasileira, seu início no Atlântico sul deveu-se à presença de pescadores estadunidenses em meados do século XVIII, situação que provocou no governo português o interesse pela captura. Os resultados econômicos eram sedutores, haja vista a elevada e duradoura demanda mundial por óleo e barbatanas de baleia, o primeiro para iluminação de casas e calafetagem de embarcações, por exemplo, e as segundas para a fabricação de variados itens (Ellis, 1972).

Durante décadas caracterizada como monopólio do governo português, que concedia a exploração mediante contratos e o pagamento de direitos, a pesca e as ações vinculadas, especialmente a extração de óleo, deram origem a várias armações na Província de Santa Catarina. 
Foram estas as estruturas criadas: Armação da Piedade (1746), a maior do Brasil meridional, situada em área do atual Município de Governador Celso Ramos; Armação de Sant'Ana de Lagoinha (1772), na atual localidade de Armação do Pântano do Sul, na Ilha de Santa Catarina; Armação de São João Batista de Itapocoróia (1778), no atual Município de Penha; Armação de São Joaquim de Garopaba (1795), no atual Município de Garopaba; e Armação de Imbituba (1796), no atual Município de Imbituba.

O período de grande captura durou pouco, todavia. De fato, a atividade apresentou declínio já desde o final do século XVIII.

Em 1785, o francês Jean-François G. de La Pérouse anotou que "A pesca da baleia é muito abundante: mas é uma propriedade da Coroa, arrendada a uma companhia de Lisboa [...]." (Ilha..., 1979, p. 122). O naturalista alemão Georg H. von Langsdorff, observando a prática em 1803, escreveu:“[...] o empreendimento da caça à baleia e produção do óleo é grande e oferece trabalho e sustento a algumas centenas de almas [...]." (Ilha..., 1979, p. 189). Mas o inglês John Mawe, passando pelo Desterro em 1806 ou 1807, assinalou que "[...] a quantidade de baleias que apanham agora é inferior à dos primeiros tempos, quando a média atingida variava de trezentas a quatrocentas, por estação de pesca." (Ilha..., 1979, p. 206). Quase duas décadas depois, em 1825, o suíço-alemão Carl F. G. Seidler cravava: “[...] em vez das 400 a 500 baleias anuais, só se pescam 6 a 8 [...].” (Ilha..., 1979, p. 304).

Contribuiu fortemente para a redução a intensa concorrência de baleeiros de origem sobretudo estadunidense, além de britânica, entre outras. Sua base era uma capacidade de apresamento e beneficiamento muito superior à existente no Brasil, afetando a presença do cetáceo no Atlântico sul. Tal situação não escapou à observação de Boiteux (1914, p. 12), segundo a qual "Apresentaram-se em nossos mares inummeros baleeiros norte-americanos e taes depredações commetteram que afugentaram d'elles, por muito tempo, as baleias."

Alvará emitido pela coroa portuguesa em 24 de abril de 1801, abolindo o regime de contratos e, assim, liberando a pesca, não resultou em retomada da atividade (Ellis, 1958). Tanto assim que, em discurso perante a Assembleia Legislativa em $1^{\circ}$ de março de 1838 , o presidente da Província de Santa Catarina assinalou: 
A pesca das Baleias, que em outro tempo tão productiva foi, acha-se hoje mui reduzida; poucas vantagens promette, e essas mesmas contingentes. Geralmente se attribue a raridade do peixe à perseguição, que lhe fazem os pescadores estrangeiros, nas proximidades da Costa, e até das Armaçoens. (Discurso..., 1838, p. 16)

Quase um decênio antes, Brito (1829, p. 65), outro presidente provincial, pronunciara-se em diapasão semelhante:

A pesca das Balêas, e a extracçao do azeite destes cetáceos he outro ramo de indústria dos habitantes desta Capitanía; e sem duvida aquelle que maiores interesses tem dado ao Estado; porêm acha-se hoje em grande decadencia, e cedo o veremos totalmente extincto, se quanto antes nao se tomarem as convenientes medidas $[\ldots]$.

Nesse processo, instalou-se conjuntura em que os britânicos passaram a suprir as necessidades brasileiras de, entre outros, óleo ("azeite de peixe”) para iluminação. O início desse fornecimento aconteceu na segunda década do século XIX, a reboque da abertura dos portos determinada em 1808. A importação cresceu a partir do término do monopólio da captura da baleia, o que aconteceu em 1801 por meio do Alvará de 24 de abril, e foi “[...] favorecida pelo tratado de Comércio de 1810 e pela posterior influência britânica no Brasil independente [...]. Daí por diante a indústria baleeira do Brasil pertenceria ao passado." (Ellis, 1972, p. 353).

Essa derrocada cevou o quadro de adversidades da Província de Santa Catarina na primeira metade do século XIX. La Pérouse constatou, em 1785, que "Os habitantes não passam de meros espectadores desta pesca, que não lhes traz nenhum proveito.” (Ilha..., 1979, p. 122). Entretanto, a economia local ressoava, de algum modo, os impulsos oriundos dessa prática, seja pela associada demanda por alimentos e outros tipos de produtos, seja pelas necessidades de transporte. E as próprias atividades diretamente ligadas à pesca, como Langsdorff notou em 1803, envolviam muitas pessoas, em particular “[...] escravos negros, que têm a executar os trabalhos mais duros durante todo o ano [...]" (Ilha..., 1979, p. 189).

A vinculação entre aquelas atividades e o uso dessa mão de obra igualmente transparece no registro de Mawe, efetuado em 1806 ou 1807, 
sobre a Armação da Piedade: "Neste posto trabalham cerca de 150 negros [...]." (Ilha..., 1979, p. 206). Assim, mencionar a pesca da baleia leva a falar da presença de escravos em Santa Catarina naquele período. É fato que essa província nunca despontou nesses termos no Brasil, mas o uso da mão de obra escrava cresceu em intensidade no seu território durante a segunda metade do século XVIII, em linha com os propósitos econômicos e mesmo geopolíticos do governo português com respeito ao Brasil meridional.

Em Santa Catarina, esses cativos trabalhavam sobretudo em engenhos de farinha e açúcar e na pecuária, segundo a análise de Mamigoniam e Bissigo (2018). O abastecimento local dessa mão de obra implicava principalmente compras internas, embora Mamigonian (2005) mencione a partida de embarcações negreiras do litoral catarinense para a África entre 1843 e 1852.

Esse período, cabe assinalar, insere-se na vigência das condições ligadas ao tratado entre Brasil e Grã-Bretanha, ratificado em 1827, que proibiu o tráfico desde 1830. Referindo-se ao respectivo contexto, o suíço-alemão Carl F. G. Seidler, que esteve no Desterro em 1825, indicou a continuidade da chegada de "[...] navios carregados, apenas com a diferença que agora têm de ser contrabandeados [...] a costa brasileira rica em enseadas oferece suficientemente ancoradouros para os navios negreiros." (Ilha..., 1979, p. 312).

Durante o século XIX, foi progressivo o encolhimento do contingente cativo na província, especialmente após 1850. A compilação de dados realizada por Silva (1951) evidencia a contração: em 1804, nada menos que quatro em cada dez habitantes amargava a condição escrava; quase setenta anos depois, a proporção recuara para patamar de 10\% a $12 \%$ (Tabela 1). Piazza (1999) sugere terem influenciado esse processo a Lei Eusébio de Queiroz, de 4 de setembro de 1850, que previu medidas de combate ao tráfico (Brasil, 1850) - em que pese o implícito e decorrente incentivo ao comércio entre as províncias -, e o crescimento da imigração de origem europeia para o sul do Brasil, envolvendo notadamente alemães, italianos e poloneses. 
Tabela 1 - Província de Santa Catarina: evolução populacional, especificando a condição livre e escrava, entre 1804 e 1870

\begin{tabular}{|c|c|c|c|c|c|c|}
\hline \multirow[t]{2}{*}{ AnOS } & \multicolumn{2}{|c|}{ POPULAÇÃO LIVRE } & \multicolumn{2}{|c|}{ POPULAÇÃO ESCRAVA } & \multicolumn{2}{|c|}{ POPULAÇÃO TOTAL } \\
\hline & $\mathrm{N}^{\mathrm{o}}$ & $\%$ & $\mathrm{~N}^{\mathrm{o}}$ & $\%$ & $\mathrm{~N}^{\mathrm{o}}$ & $\%$ \\
\hline 1804 & 6.142 & 60,6 & 4.000 & 39,4 & 10.142 & 100 \\
\hline 1810 & 24.331 & 77,2 & 7.203 & 22,8 & 31.534 & 100 \\
\hline 1813 & 25.471 & 77,3 & 7.478 & 22,7 & 32.949 & 100 \\
\hline 1819 & 34.859 & 79,2 & 9.172 & 20,8 & 44.031 & 100 \\
\hline 1838 & 49.966 & 78,5 & 13.658 & 21,5 & 63.624 & 100 \\
\hline 1839 & 51.576 & 78,6 & 14.062 & 21,4 & 65.638 & 100 \\
\hline 1841 & 54.678 & 81,3 & 12.540 & 18,7 & 67.218 & 100 \\
\hline 1844 & 58.432 & 80,2 & 14.382 & 19,8 & 72.814 & 100 \\
\hline 1847 & 60.743 & 81,3 & 13.942 & 18,7 & 74.685 & 100 \\
\hline 1850 & 70.789 & 82,5 & 14.966 & 17,5 & 85.755 & 100 \\
\hline 1851 & 72.391 & 82,8 & 15.057 & 17,2 & 87.448 & 100 \\
\hline 1854 & 87.364 & 86,0 & 14.195 & 14,0 & 101.559 & 100 \\
\hline 1855 & 88.485 & 83,8 & 17.119 & 16,2 & 105.604 & 100 \\
\hline 1856 & 92.922 & 83,6 & 18.187 & 16,4 & 111.109 & 100 \\
\hline 1857 & 104.425 & 85,0 & 18.408 & 15,0 & 122.833 & 100 \\
\hline 1858 & 108.655 & 85,0 & 19.131 & 15,0 & 127.786 & 100 \\
\hline 1859 & 98.281 & 85,8 & 16.316 & 14,2 & 114.597 & 100 \\
\hline 1867 & 104.459 & 87,6 & 14.722 & 12,4 & 119.181 & 100 \\
\hline 1868 & 135.000 & 90,0 & 15.000 & 10,0 & 150.000 & 100 \\
\hline 1870 & 104.459 & 87,6 & 14.722 & 12,4 & 119.181 & 100 \\
\hline
\end{tabular}

Fonte: Silva (1951, p. 115-116).

Obs.: para o ano de 1841 os dados originais apresentam dois tipos de informação: a população total é a mesma, de 67.218, mas a distribuição entre livres e escravos tem uma pequena diferença, de 80 pessoas; assim, utilizou-se a média dos números indicados para livres e escravos.

A Tabela 2, baseada no primeiro recenseamento populacional realizado no Brasil (em 1872), mostra a distribuição dos cativos no interior da província. Pouco menos de 2/3 figuravam no conjunto formado por Desterro, São José, São Francisco e Laguna, áreas de colonização antiga. Esses mesmos locais tinham as maiores proporções de população escrava nas respectivas populações totais; também merece menção Lages, em cujas lides campeiras esses trabalhadores eram muito utilizados. Em Joinville foi registrada a menor presença, em quantidade e em proporção, e também em Itajaí a parcela era pequena, no patamar de 5\%. Ambos eram espaços de ocupação mais recente e forte incidência de imigração europeia. 
Tabela 2 - Província de Santa Catarina: população livre, escrava e total (1872)

\begin{tabular}{|c|c|c|c|}
\hline Municí́pios & $\begin{array}{c}\text { População } \\
\text { LIVRE }\end{array}$ & $\begin{array}{c}\text { População } \\
\text { ESCRAVA }\end{array}$ & $\begin{array}{c}\text { População } \\
\text { TOtAL }\end{array}$ \\
\hline \multicolumn{4}{|c|}{ Número de pessoas } \\
\hline Desterro & 22.769 & 2.940 & 25.709 \\
\hline São Miguel & 9.357 & 1.071 & 10.428 \\
\hline São José & 20.571 & 2.234 & 22.805 \\
\hline São Sebastião das Tijucas & 9.356 & 1.031 & 10.387 \\
\hline N. S. da Graça do Rio São Francisco & 13.635 & 1.692 & 15.327 \\
\hline Itajahy & 20.421 & 1.092 & 21.513 \\
\hline Lages & 7.447 & 1.041 & 8.488 \\
\hline N.S. da Conceição dos Coritibanos & 4.008 & 319 & 4.327 \\
\hline Joinville & 7.575 & 75 & 7.650 \\
\hline Laguna & 17.948 & 2.470 & 20.418 \\
\hline Tubarão & 11.731 & 1.019 & 12.750 \\
\hline Total & 144.818 & 14.984 & 159.802 \\
\hline \multicolumn{4}{|c|}{$\%$ sobre o total de cada município } \\
\hline Desterro & 88,6 & 11,4 & 100 \\
\hline São Miguel & 89,7 & 10,3 & 100 \\
\hline São José & 90,2 & 9,8 & 100 \\
\hline São Sebastião das Tijucas & 90,1 & 9,9 & 100 \\
\hline N. S. da Graça do Rio São Francisco & 89,0 & 11,0 & 100 \\
\hline Itajahy & 94,9 & 5,1 & 100 \\
\hline Lages & 87,7 & 12,3 & 100 \\
\hline N. S. da Conceição dos Coritibanos & 92,6 & 7,4 & 100 \\
\hline Joinville & 99,0 & 1,0 & 100 \\
\hline Laguna & 87,9 & 12,1 & 100 \\
\hline Tubarão & 92,0 & 8,0 & 100 \\
\hline Total & 90,6 & 9,4 & 100 \\
\hline \multicolumn{4}{|c|}{ \% sobre o total de cada população } \\
\hline Desterro & 15,7 & 19,6 & 16,1 \\
\hline São Miguel & 6,5 & 7,1 & 6,5 \\
\hline São José & 14,2 & 14,9 & 14,3 \\
\hline São Sebastião das Tijucas & 6,5 & 6,9 & 6,5 \\
\hline N. S. da Graça do Rio São Francisco & 9,4 & 11,3 & 9,6 \\
\hline Itajahy & 14,1 & 6,9 & 13,5 \\
\hline Lages & 5,1 & 6,9 & 5,3 \\
\hline N.S. da Conceição dos Coritibanos & 2,8 & 2,1 & 2,7 \\
\hline Joinville & 5,2 & 0,5 & 4,8 \\
\hline Laguna & 12,4 & 16,5 & 12,8 \\
\hline Tubarão & 8,1 & 6,8 & 8,0 \\
\hline Total & 100 & 100 & 100 \\
\hline
\end{tabular}

Fonte: elaborado pelo autor com base em dados de Recenseamento do Brazil (1872). 


\section{Acenos da imigração europeia perante as adversidades}

Com os contornos mencionados, o quadro econômico da Província de Santa Catarina provocava inquietação nos meios políticos e administrativos locais. Explorar possibilidades que sinalizassem maior vitalidade produtiva e comercial era iniciativa considerada estratégica.Jogar a carta do impulso à colonização envolvendo europeus foi opção abertamente defendida pelas autoridades.

De fato, em relatório apresentado no dia 5 de abril de 1836 à Assembleia Legislativa provincial, o Presidente José Mariano de Albuquerque Cavalcante assim se manifestou sobre os problemas de Santa Catarina.

A naturesa, entre os dons de que foi pródiga com este País abençoado o favoreceu com hum clima, alem de benigno, próprio para quase todas as producções [...]. A população porem não he proporcionada à extenção do território; faltão-nos braços que fação valer este torrão precioso, ate agora em grande parte improductivo por inculto, e falta-nos também o soccorro das Artes para o uso e emprego de maquinas que ajudem e facilitem os trabalhos agrícolas. Estes braços, estes auxílios só nos podem vir da Europa, onde a população superabunda, e onde as Artes tem chegado ao maior apuro. Cumpre pois que por meio de Colonisações chamemos ao nosso País homens activos e industriosos, e supramos com braços livres esses inertes e aviltados pelos ferros da escravidão que nos fornecia o abominável trafico de carne humana. (Relatório..., 1836, p. 11)

Essa posição de enfática defesa da imigração europeia para a província, em vista das carências locais para promover a economia e do impacto da redução do trabalho escravo, foi reiterada no ano seguinte pelo novo presidente, Jose Joaquim Machado de Oliveira, em pronunciamento perante a Assembleia Legislativa em $1^{\circ}$ de março de 1837.

A nossa indústria agricula precisa de hum impulso benéfico para que não cáia em desfalecimento com a cessação do trafico de escravatura; e este impulso só de vós póde provir seja pela confecção de Leis apropriadas à colonização, seja em conferir meios à Administração para levar à pratica tão importante objecto. (Falla..., 1837, p. 14) 
O tema persistiu como de perfil estratégico na agenda da província. Quatro anos mais tarde, o novo presidente, Brigadeiro Antero Jozé Ferreira de Brito, expôs da seguinte maneira as suas ideias a respeito.

Extincto de direito, e devemos esperar que o seja tambem de facto, o trafico impolítico e inhumano de escravos, cumpre atrair ao Paiz por meio da Colonisação homens que se dediquem ao trabalho com o ardor que inspira a esperança de fruil-o, e que nos venhão ensinar novos methodos de agricultar, e a construcção e uso das maquinas e instrumentos hoje tão vulgarisadas na Europa, com o soccorro das quaes, ao passo que se diminue o trabalho, torna-se ele mais perfeito, e poupa-se o emprego de grande numero de braços. (Falla..., 1841)

É dificil dizer que tais opiniões prefigurassem o tipo de pensamento político que, em livro de Tavares Bastos intitulado A Província, advogava pela descentralização, a rigor, pela federalização do Brasil (Bastos, 1870, p. 90). $\mathrm{Na}$ opinião do autor, no marco da vislumbrada federalização teriam “[...] as províncias iniciativa para abrir caminho ao progresso; de si mesmas dependia o seu porvir: não ficariam a desfalecer aguardando o illusorio impulso do governo central".

Esse autor também se debruçou sobre o problema das imigrações. Com respeito às iniciativas para promovê-las, Bastos (1870, p. 292) se declarou persuadido "[...] de que uma das mais poderosas causas do naufragio de tantas tentativas de immigração tem sido a louca pretenção de se dirigir do Rio de Janeiro as complexas operações de um serviço disseminado por tão vasto paiz".

$\mathrm{Na}$ verdade, a visão provincial sobre a imigração europeia estava alinhada com o que preconizava o governo central, antes e depois da Independência. Fazia tempo que povoar o país com imigrantes daquela origem tornara-se ação estratégica em escala ampla, e núcleos com esse perfil foram criados em alguns locais no Brasil.Após 1822, ganhou maior vulto e repercutiu mais fortemente o interesse em ocupar e laborar terras novas com agricultores brancos e livres.

O sul do Brasil foi especialmente implicado nesse processo. Como assinalou Carvalho (1910, p. 101, tradução nossa), "Repetiu-se frequentemente que a história do Brasil meridional é a história da colonização; poder-se-ia dizer além disso que a história dessa colonização é a das necessidades econômicas do país e em particular a da mão de obra que o explora". 
Em Santa Catarina, o movimento em questão intensificou-se na segunda metade do século XIX, sob o impulso das companhias de colonização. Referindo ao que talvez tenha sido a experiência que logrou maior divulgação, em 1850 foi fundada (com alemães) a colônia de Blumenau (Hering, 1987). O empreendimento tornou-se um " $[\ldots]$ centro de expansão colonial, que se distribuiu por todo o vale do Itajaí-açu e seus tributários." (Cabral, 1968, p. 204). Em 1851, com numerosos suíços, noruegueses e alemães, surgiu a Colônia Dona Francisca, germe de Joinville (Ficker, 1965).

Mas a Província de Santa Catarina registrara movimentos de colonização desde o início do século XIX. Boiteux (1920) informou que, em 1827, 139 colonos alemães fundaram o núcleo Rio Negro; no ano seguinte, 523 alemães foram instalados na estrada que ligava o Desterro a Lages, disso resultando a Colônia São Pedro de Alcântara, logo deparada com problemas (ocasionando abandonos) devido às condições locais e à falta de recursos.Várias outras iniciativas foram registradas por Cabral (1968), com diferentes origens migratórias e graus de sucesso.

Todavia, em matéria de peculiaridade, provavelmente nenhum experimento registrado na província supere o ocorrido na década de 1840 na área do Saí, localizada no território correspondente ao atual Município de Francisco do Sul. O clima de apreensão com o quadro político no Brasil do Segundo Reinado, do qual não estavam ausentes as condições socioeconômicas de diferentes províncias, foi bem observado pelo Dr. Benoît Jules Mure, médico nascido em Lyon, em 1809, e seguidor das ideias de François Marie Charles Fourier, socialista utópico nascido em Besançon em 1772.

Tendo viajado ao Brasil em novembro de 1840, objetivando instalar núcleo de colonização na forma de um Falanstério (neologismo criado pela contração entre falange e monastério) que operasse, com fidelidade ao fourierismo, sob o signo do associativismo, o médico convenceu o governo imperial sobre a importância de tal iniciativa.A defesa do empreendimento ocorreu mediante exposição direta do projeto ao governo brasileiro e também via publicações no Jornal do Commercio, do Rio de Janeiro.

Uma dessas publicações tomou a forma de uma carta, publicada por esse jornal em 17 de dezembro de 1840, na qual se listaram as competências dos franceses que se pretendia trazer. Tratava-se de fabricantes 
de máquinas a vapor, máquinas para fiar linho, instrumentos para lavrar madeira, torneiras para conservar gases comprimidos. Também se falou de profissionais familiarizados com trabalhos metalúrgicos, e ainda de arquitetos, carpinteiros e pedreiros, além de agricultores (Carta..., 1840).

Com apoio inclusive financeiro do governo imperial, o Dr. Mure escolheu, durante o ano de 1841, a referida área do Saí para abrigar o empreendimento. No final daquele ano, chegava ao Rio de Janeiro a primeira leva de colonos franceses, de passagem para o sul do país. $\mathrm{O}$ acontecimento foi efusivamente saudado em editorial do Jornal do Commercio de 21 de dezembro de 1841: "Acaba o Rio de Janeiro de ser testemunha de hum espetáculo [...] digno de attrahir a atenção dos amigos do Brazil [...] Possa ele bem depressa ser testemunha de hum [...] espectaculo nessa terra do Sahy [...]" (Editorial..., 1841, p. 1).

As expectativas eram elevadas na Província de Santa Catarina, haja vista o adverso quadro socioeconômico prevalecente. Refletiu o anseio local o discurso do Presidente, Antero Jozé Ferreira de Brito, perante a Assembleia em $1^{\circ}$ de março de 1842.

Ser-vos-há grato saber que o Governo Imperial, auctorisado pela Lei Geral No 243, tem mandado fundar huma Colonia Industrial Societaria, no Municipio de S. Francisco, para a qual Houve Sua Magestade O Imperador por bem Conceder duas legoas quadradas de terra devoluta na Península do Sahy por Decreto de 11 de Dezembro ultimo, que aprovou as condiçoens do Contracto celebrado pelo Governo com o Doutor Bento Mure, Emprezario da Colonia, o qual no praso de humanno deve ter n'ella quinhentos Colonos societários. Os primeiros, em numero de cem, chegarão ao seu destino em Janeiro deste anno, e tratando-se ainda dos primeiros arranjos para o seu estabelecimento, nada se póde dizer sobre a empresa, da qual com tudo he permitido esperar que grandes bens resultarão à Provincia, visto que os Societarios, devendo ser pessoas de boa morigeração, e dotados de talendo e industria, darão valor às riquesas naturaes que não temos podido, ou sabido aproveitar; farão avultar os nossos productos, e os aperfeiçoamentos materiaes que introdusirem, servirão de exemplo e de estimulo aos habitantes do Paíz para os imitarem. (Falla..., 1842, p. 27)

Mas a investida, que chegou a registrar a presença de mais de 200 colonos na área destinada ao Falanstério, teve fôlego curto. Os motivos do insucesso foram objeto de abordagens, por exemplo, em Boiteux 
(1944), S. Thiago (1995) e Lins (2010). Têm destaque nessas análises os vários percalços enfrentados, inclusive na chegada das primeiras levas de franceses, e a incontornável cisão interna que se processou.

Daí que, já em $1^{\circ}$ de março de 1843, o Presidente da Província dizia à Assembleia que "Às fagueiras esperanças de que vos dei parte no meu ultimo Relatorio, à cerca da fundação da Colonia Industrial franceza [...], succederãm serias apreensões de que não seria bem sucedido o intento, as quaes desgraçadamente vemos quase realizadas." (Falla..., 1843, p. 16). Um ano depois, o tom era este:

Prosperam as Colonias estabelecidas na Provincia, menos a do Sahy, que hoje, com nove homens, e sem estabelecimento algum, quer agrícola, quer industrial, toca a sua completa aniquilação, e sempre foi isto para temer a respeito de uma empresa colonial em que se saltou por sima de todas as regras que a experiencia tem ensinado [...]. (Falla..., 1844, p. 25)

A rapidez com que foi saudada e acolhida a iniciativa foi praticamente a mesma com que, diante dos fatos, passou-se a execrar a tentativa fourierista no Saí. Ao mesmo tempo, cuidou-se de salientar os contrastes com os empreendimentos colonizadores vistos como bem-sucedidos, estimuladores dos avanços subsequentes nas medidas em prol da imigração e da colonização. O pano de fundo persistiu: as dificuldades e necessidades que caracterizavam Santa Catarina, em grande parte ligadas às consequências locais de políticas definidas e executadas em escalas mais amplas.

\section{Considerações finais}

Como parte do sistema português, e depois - apesar de vínculos com a Grã-Bretanha que faziam ressoar fortemente os interesses britânicos no plano local - como país independente, o Brasil - e a Província de Santa Catarina - vivenciou opressão dos tipos manu militari e comercial entre o final do século XVIII e meados do século XIX.A proibição portuguesa às atividades fabris na colônia, especialmente as têxteis, respondeu pelo essencial do primeiro tipo. A aguda concorrência de produtos principalmente britânicos, amparada por acordos amplamente favoráveis à principal potência mundial no período, representou as bases do segundo. 
Em Santa Catarina, as dificuldades causadas por agentes externos, ou por condições externamente produzidas, não se limitaram às atividades têxteis. O declínio da pesca da baleia, com reflexos nas associadas atividades em terra firme (extração do óleo, aproveitamento de partes dos cetáceos, transportes), reverberou em retração das oportunidades de ocupação e geração de renda.Amplamente falando, o quadro socioeconômico instalado em Santa Catarina era de escassas oportunidades, fazendo da disseminada pobreza um traço saliente e inquietante. Tudo somado, incluindo as circunstâncias relacionadas ao uso do trabalho escravo, a província se viu perante a necessidade de vislumbrar e explorar novas possibilidades.

As lideranças políticas locais enxergaram no estímulo à imigração com origem europeia um caminho a ser privilegiado, notadamente desde países ou regiões onde era maior a familiaridade com atividades industriais. Essa conduta mostrava-se alinhada com decisões tomadas e com medidas protagonizadas no governo central. Todavia, durante a primeira metade do século XIX - o recorte temporal básico deste estudo -, a experiência migratória nos termos pretendidos exibiu resultados em que se combinaram motivos para otimismo e esperança sobre o futuro próximo e também para franca decepção, neste caso com críticas virulentas, oriundas de vários meios, ao que se protagonizou em diferentes esferas de poder político e administrativo.

Portanto, assim como se nota na atualidade, sob o signo da chamada globalização, também historicamente as realidades locais costumam ser afetadas por processos urdidos em níveis mais amplos, na forma de determinações de natureza estrutural. E também historicamente tenta-se encontrar saídas, no âmbito local, para as adversidades assim surgidas ou agravadas, o grau de sucesso revelando-se vinculado a diversos e imponderáveis fatores. Os sinais e pistas explorados neste estudo sugerem que esse foi o caso na Província de Santa Catarina na primeira metade do século XIX.

\section{Referências}

AMIN, S. Le développement inégal: essai sur les formations sociales du capitalisme périphérique. Paris: Les Éditions de Minuit, 1973. 
BASTOS,A. C.T. A província: estudo sobre a descentralisação no Brazil. Rio de Janeiro: B. L. Garnier, 1870. Disponível em: <http://www2.senado.leg.br/bdsf/item/ id/220526>. Acesso em: 29 jan. 2019.

BOITEUX, H. O Falanstério do Saí. Revista do Instituto Histórico e Geográfico de Santa Catarina, v. 12, p. 47-90, 1944.

BOITEUX, L.A.A pesca da baleia. Revista Trimensal do Instituto Histórico e Geográfico de Santa Catarina, v. 3, p. 3-12, 1914.

BOITEUX, L. A. Pequena historia catharinense. Florianópolis: Imprensa Official, 1920.

BRAUDEL, F. Civilização material, economia e capitalismo: séculos XV-XVIII.V. 2. - O jogo das trocas. São Paulo: Martins Fontes, 1998a.

BRAUDEL, F. Civilização material, economia e capitalismo: séculos XV-XVIII.V. 3. - O tempo do mundo. São Paulo: Martins Fontes, 1998b.

BRITTO, J. G. de L. Pontos de partida para a história econômica do Brasil. 2. ed. São Paulo: Companhia Editora Nacional, 1939.

CABRAL, O. R. História de Santa Catarina. Florianópolis: Imprensa da Universidade Federal de Santa Catarina, 1968.

CABRAL, O. R. Nossa Senhora do Destêrro - Memória I. Florianópolis: Imprensa da Universidade Federal de Santa Catarina, 1972a.

CABRAL, O. R. Nossa Senhora do Destêrro - Notícia II. Florianópolis: Imprensa da Universidade Federal de Santa Catarina, 1972b.

CARVALHO, C. M. D. de. Le Brésil meridional: étude économique sur les états du sud - S. Paulo, Paraná, Santa-Catharina et Rio-Grande-do-Sul. Paris: E. Despossês, 1910.

DINIZ, A. F. Centralização política e concentração de riqueza: as finanças do Império Brasileiro no período de 1830 a 1889. História e Economia, v. 1, n. 1, p. 47-65, 2005.

ELLIS, M. Aspectos da pesca da baleia no Brasil colonial (III). Revista de História, v. 16, n. 34, p. 379-424, 1958.

ELLIS, M. Norte-americanos no Atlântico brasileiro - um inédito de José Bonifácio de Andrada e Silva sobre o conceito de mar territorial e o direito de pesca. Revista de História, v. 46, n. 94, p. 339-367, 1972.

FICKER, C. História de Joinville: subsídios para a crônica da Colônia Dona Francisca. 2.ed. Joinville: Impressora Ipiranga, 1965.

FOULCAULT, M. A arqueologia do saber. Rio de Janeiro: Forense Universitária, 2007.

FRANK, A. G. L'Accumulation mondiale: 1500-1800. Paris: Calmann-Lévy, 1977.

FURTADO, C. (1959). Formação econômica do Brasil. São Paulo: Editora Nacional, 1987.

GINZBURG, C. Morelli, Freud and Sherlock Holmes: clues and scientific method. History Workshop Journal, v. 9, n. 1, p. 5-36, 1980.

HERING, M. L. R. Colonização e indústria no Vale do Itajaí: o modelo catarinense de desenvolvimento. Blumenau: Ed. da FURB, 1987.

HOPKINS, T. K.; WALLERSTEIN, I. Capitalism and the incorporation of new zones into the world-economy. Review, v. 10, n. 5/6, suppl., p. 763-779, 1987.

HÜBENER, L. M. O comércio da cidade do Desterro no século XIX. Florianópolis: Ed. da Universidade Federal de Santa Catarina, 1981. 
ILHA de Santa Catarina: relatos de viajantes estrangeiros nos séculos XVIII e XIX. Florianópolis: Assembleia Legislativa do Estado de Santa Catarina, 1979.

LÉNINE, V. I. U. (1917). L'impérialisme, stade suprême du capitalisme. Paris: Editions Sociales, 1979.

LESSA, C. O Rio de todos os brasis. Rio de Janeiro: Record, 2000.

LINS, H. N. Fourierismo no Brasil meridional: a saga do Falanstério do Saí (1841-1844). História Econômica \& História de Empresas, v. 13, n. 1, p. 31-72, 2010.

LUZ, N.V. A luta pela industrialização do Brasil. São Paulo: Alfa-Omega, 1978.

MAMIGONIAN, B. G. O litoral de Santa Catarina na rota do abolicionismo britânico, décadas de 1840 e 1850. In: II ENCONTRO "ESCRAVIDÃO E LIBERDADE NO BRASIL MERIDIONAL”, Porto Alegre, Universidade Federal do Rio Grande do Sul, 26 a 28 out. 2005. Disponível em: <http://www.escravidaoeliberdade. com.br/site/images/Textos $2 /$ beatriz $\% 20$ mamigonian\%20completo.pdf $>$. Acesso em: 12 fev. 2019.

MAMIGONIAN, B. G.; BISSIGO, D. N. População de origem africana. In: ROCHA, Isa de O. (Org.). Atlas geográfico de Santa Catarina: população - fascículo 3. Florianópolis: Ed. Da UDESC, 2018, p. 72-88.

MANDEL, E. Tratado de economía marxista. T. II. México, DF: Ediciones Era, 1969.

MARKUSEN, A. R. Região e regionalismo: um enfoque marxista. Espaço \& Debates, v. 1, n. 2, p. 61-99, 1981.

MARX, K. Le capital. (1867). Livre Premier. Moscou: Éditions Du Progrès, 1982.

NOVAIS, F A. (1966). A proibição das manufaturas no Brasil e a política econômica portuguesa no fim do século XVIII. Revista de História, n. 142-143, p. 213-237, 2000.

PIAZZA, W. F. A escravidão negra numa província periférica.Tubarão: Ed. Da UNISUL, 1999.

PRADO JÚNIOR, C. (1942). Formação do Brasil contemporâneo: colônia. São Paulo: Editora Brasiliense, 1961.

QUIJANO,A.;WALLERSTEIN, I. De l'américanité comme concept, ou les Amériques dans le système mondial moderne. Revue Internationale des Sciences Sociales, n. 134, p. 617-625, 1992.

S.THIAGO, R. Fourier: utopia e esperança na Península do Saí. Blumenau:Ed. da FURB; Florianópolis: Ed. da UFSC, 1995.

SAINT-HILAIRE, A. de. (1851). Viagem a província de Santa Catharina (1820). São Paulo: Companhia Editora Nacional, 1936.

SILVA, A. da. A Ilha de Santa Catarina e sua terra firme: estudo sobre o governo de uma capitania subalterna (1738-1807). São Paulo: USP, 2008. Tese (Doutorado em História).

SILVA, J. N. de S. e. Investigações sôbre os recenseamentos da população geral do Império. Rio de Janeiro: Conselho Nacional de Estatística, 1951. (Documentos Censitários Série B - Número 1).

SIMONSEN, R. C. (1937). História econômica do Brasil: 1500-1820. Brasília: Senado Federal, 2005. Disponível em:<http://www2.senado.leg.br/bdsf/bitstream/handle/ id/1111/749413.pdf?sequence=4>. Acesso em: 31 jan. 2019. 
TAUNAY, A. M.A. d'E. Paisagens brasileiras. São Paulo: Melhoramentos, 1926.

TILLY, C. Coercion, capital, and european states, AD 990-1990. Cambridge: Basil Blackell, 1990.

VARNHAGEN, F. A. de. Historia geral do Brazil. Tomo II. Rio de Janeiro: E. e H. Lamemmert, 1857. Disponível em: < https://www.literaturabrasileira.ufsc.br/docum entos $/$ ?action=download\&id=89846> . Acesso em: 31 fev. 2019.

WALLERSTEIN, I. El moderno sistema mundial II. México, DF: Siglo Veintiuno, 1984.

WALLERSTEIN, I. El moderno sistema mundial III. México, DF: Siglo Veintiuno, 1998.

\section{Fontes históricas}

ALVARÁ de 5 de janeiro de 1875. In: SILVA, Antonio D. da. Collecção da Legislação portuguesa: desde a ultima compilação das ordenações.V. III - Legislação de 1775 a 1790. Lisboa: Typografia Maigrense, 1828, p. 370-371. Disponível em: <http:// www2.senado.leg.br/bdsf/item/id/518674>. Acesso em: 27 jan. 2019.

ALVARÁ do 1. ${ }^{\circ}$ de abril de 1808. In:ARAÚJO, José P. de F. N. de. Collecção chronologica das leis, decretos, resoluções de consulta, provisões, etc., etc., do Império do Brazil, desde o anno de 1808 até 1831 inclusive, contendo: além do que se acha publicado nas melhores collecções, para mais de duas mil peças inéditas. V. 1. Rio de Janeiro: Typ. Imp. e Const. De J.Villeneuve e Comp. 1836, p. 4. Disponível em: <http://www2.senado. leg.br/bdsf/handle/id/227320>. Acesso em: 27 jan. 2019.

BRASIL. Presidência da República. Casa Civil. Subchefia de Assuntos Jurídicos. Lei n. 581 , de 4 de setembro de 1850. Estabelece medidas para a repressão do trafico de africanos neste Imperio. Disponível em: <http://www.planalto.gov.br/ccivil_03/ leis/lim/LIM581.htm> Acesso em: 12 fev. 2019.

BRASIL. Presidência da República. Casa Civil. Subchefia de Assuntos Jurídicos. Decreto de 11 de junho de 1808. Marca os direitos das mercadorias entradas nas AIfandegas do Brazil e das reexportadas. Rio de Janeiro, 1808. Disponível em: <http:// www.planalto.gov.br/ccivil_03/decreto/historicos/dim/DIM-11-6-1808.htm>. Acesso em: $1^{\circ}$ fev. de 2019.

BRITO, Paulo J. M. de. Memoria politica sobre a Capitania de Santa Catharina. Lisboa: Typografia da Academia Real das Sciencias, 1829.

CARTA Régia de 28 de janeiro de 1808. In: Coleção de Leis do Brasil - 1808. Brasília: Câmara dos Deputados, v. 1, n. 1, p. 1.

CARTA do Dr. Mure, publicada pelo Jornal do Commercio (RJ), em 17 dez. 1840, p. 2-3, na Coluna "Colonização" (Biblioteca Nacional).

DISCURSO pronunciado na abertura da Assemblea Legislativa da Provincia de Santa Catharina na $1^{\text {a }}$ Sessão Ordinária da $2^{\mathrm{a}}$ Legislatura de 1838 pelo respectivo Presidente o Brigadeiro João Carlos Pardal, Cidade do Desterro em o $1^{\circ}$ de março de 1838. Desterro:Typographia Provincial, 1838 Disponível em: < http://ddsnext.crl. $\mathrm{edu} / \mathrm{titles} / 189 \# ? \mathrm{c}=0 \& \mathrm{~m}=3 \& \mathrm{~s}=0 \& \mathrm{cv}=17 \& \mathrm{r}=0 \& \mathrm{xywh}=-1515 \% 2 \mathrm{C}-$ -1\%2C4981\%2C3514 > Acesso em: 7 fev. 2019. 
DISCURSO pronunciado pelo presidente da Provincia de Santa Catharina, o Marechal de Campo Francisco Joze de Souza Soares d'Andrea, na sessão ordinária do anno de 1840 aberta no primeiro dia do mez de março. Disponível em: < http://ddsnext. crl.edu/titles $/ 189 \# ? \mathrm{c}=0 \& \mathrm{~m}=5 \& \mathrm{~s}=0 \& \mathrm{cv}=1 \& \mathrm{r}=0 \& \mathrm{xywh}=-1191 \% 2 \mathrm{C}-$ -1\%2C4636\%2C3271> Acesso em: 7 de fev. 2019.

EDITORIAL do Jornal do Commercio (RJ) de 21 de dezembro de 1841, p. 1, sob o título "Colonização Industrial" (Biblioteca Nacional).

FALLA do illustrissimo e excellentissimo senhor José Joaquim Machado de Oliveira, presidente da provincia de Santa Catharina na abertura da terceira sessão da primeira legislatura provincial em o primeiro de março de 1837, decimo sexto da independencia e do imperio. Cidade do Desterro: Typographia Provincial, 1837. Disponível em: < http://ddsnext.crl.edu/titles/189\#?c=0\&m=2\&s=0\&cv=13\&r $=0 \& x y w h=975 \% 2 \mathrm{C} 848 \% 2 \mathrm{C} 842 \% 2 \mathrm{C} 594>$ Acesso em: 12 fev. 2019.

FALLA que o Presidente da Provincia de Santa Catharina o Brigadeiro Antero Jozé Ferreira de Brito dirigio à Assemblea Legislativa da mesma província na abertura da sai sessão ordinária em o $1^{\circ}$ de março de 1841. Cidade do Desterro:Typographia Provincial, 1841. Disponível em: < http://ddsnext.crl.edu/titles $/ 189 \# ? \mathrm{c}=0 \& \mathrm{~m}=7$ $\& \mathrm{~s}=0 \& \mathrm{cv}=1 \& \mathrm{r}=0 \& \mathrm{xywh}=-18 \% 2 \mathrm{C} 1933 \% 2 \mathrm{C} 2248 \% 2 \mathrm{C} 1586>$ Acesso em: $12 \mathrm{fev}$. 2019.

FALLA que o presidente da provincia de Santa Catharina, o marechal de campo graduado Antero Jozé Ferreira de Brito, dirigio à Assemblea Legislativa da mesma provincia na abertura da sua sessão ordinaria em o $1^{\circ}$ de março de 1842 . Cidade do Desterro:Typographia Provincial, 1842. Disponível em: $<$ http://ddsnext.crl.edu/ti tles $/ 189 \# ? \mathrm{c}=0 \& \mathrm{~m}=8 \& \mathrm{~s}=0 \& \mathrm{cv}=1 \& \mathrm{r}=0 \& \mathrm{xywh}=-1355 \% 2 \mathrm{C} 0 \% 2 \mathrm{C} 4628 \% 2 \mathrm{C} 3264>$ Acesso em: 15 fev. 2019.

FALLA que o presidente da provincia de Santa Catharina, o marechal de campo Antero Jozé Ferreira de Brito, dirigio à Assemblea Legislativa da mesma provincia na abertura da sua sessão ordinaria, em o $1^{\circ}$ de março de 1843 . Cidade do Desterro: Typographia Provincial, 1843. Disponível: < http://ddsnext.crl.edu/titles/189\#?c $=0 \& \mathrm{~m}=9 \& \mathrm{~s}=0 \& \mathrm{cv}=17 \& \mathrm{r}=0 \& \mathrm{xywh}=-1131 \% 2 \mathrm{C}-1 \% 2 \mathrm{C} 4197 \% 2 \mathrm{C} 2961>$ Acesso em: 15 fev. 2019.

FALLA que o presidente da provincia de Santa Catharina, o marechal de campo Antero Jozé Ferreira de Brito, dirigio à Assembléa Legislativa da mesma provincia na abertura da sua sessão ordinaria, em o $1^{\circ}$ de março de 1844 . Cidade do Desterro: Typographia Provincial, 1844. Disponível em: < http://ddsnext.crl.edu/titles/189 $\# ? \mathrm{c}=0 \& \mathrm{~m}=10 \& \mathrm{~s}=0 \& \mathrm{cv}=0 \& \mathrm{r}=0 \& \mathrm{xywh}=-861 \% 2 \mathrm{C} 190 \% 2 \mathrm{C} 3655 \% 2 \mathrm{C} 2578>$ Acesso em: 15 fev. 2019.

MEMÓRIA política de Santa Catarina. Biografia Padre Lourenço. 2018. Disponível em: <http://memoriapolitica.alesc.sc.gov.br/biografia/616-Padre_Lourenco>. Acesso em: 28 de janeiro de 2019.

MEMÓRIAS de Luiz Nunes Pires. (1829?). Florianópolis, 1967. (Documento datilografado em dezembro de 1967 com base no original).

RECENSEAMENTO do Brasil EM 1872. Rio de Janeiro: Typ. de G. Leuzinger \& 
Filhos, 1872. Disponível em: <https://biblioteca.ibge.gov.br/visualizacao/monografias/GEBIS\%20-\%20RJ/Recenseamento_do_Brazil_1872/Imperio\%20do\%20 Brazil\%201872.pdf> Acesso em: 31 jan. 2019.

RELATÓRIO do Presidente da Província de Santa Catharina na abertura da $2^{\mathrm{a}}$ Sessão da $1^{\mathrm{a}}$ Legislatura Provincial em 5 de abril de 1836. Disponível em: $<$ http:/ /ddsnext.crl.edu/titles $/ 189 \# ? \mathrm{c}=0 \& \mathrm{~m}=1 \& \mathrm{~s}=0 \& \mathrm{cv}=0 \& \mathrm{r}=0 \& \mathrm{xywh}=-44$ \%2C0\%2C2871\%2C2025> Acesso em: 12 fev. 2019.

TRATADO de commercio e navegação de 19 de fevereiro de 1810. In:ARAÚJO, José P. de F. N. de. Colleç̧ão chronologica das leis, decretos, resoluções de consulta, provisões, etc., etc., do Império do Brazil, desde o anno de 1808 até 1831 inclusive, contendo: além do que se acha publicado nas melhores collecções, para mais de duas mil peças inéditas. V. 1. Rio de Janeiro:Typ. Imp. e Const. De J.Villeneuve e Comp. 1836, p. 242-249. Disponível em: <http://www2.senado.leg.br/bdsf/handle/id/227320>.Acesso em: 27 jan. 2019. 